\title{
Constructing and Reconstructing History. University Jubilees at Aarhus University. Told and Untold, 1928-1978
}

\begin{abstract}
This chapter investigates the told and untold, when writing university jubilee histories. The case in point is Aarhus University. The text has a triple ambition. First, it shows how history was a tool and an argument for the creation of an university in Aarhus - and how it kept its legitimizing role even after the university was established in 1928. The narrative was anchored in a mix of private storytelling by members of 'the pioneering generation' and commissioned jubilee histories. Institutional as well as personal ambitions were of importance to the staging of the past. History was used, but also done. Second, I challenge some of the silences in the jubilee histories through a gendered and affective reading of institutional and private archives of some of the university's founding fathers. This approach takes its inspiration from feminist thinker Maria Tamboukou's neo-materialist reading of archives as laboratories, where silences and fragments engage the fantasy and imagination of the historian. Thirdly, I wish to contribute to the reflections on how to connect institutional jubilee histories with narratives of academic every day routine, lived and done by men and women who interact, with all the passions, conflicts, power and gendered hierarchies this entails.
\end{abstract}

\section{Introduction}

Wednesday, the $11^{\text {th }}$ of September 1946 was an important date in the history of Aarhus University. On this day, the university inaugurated its main building with the impressive aula. In October 1944, a British air raid directed towards the Gestapo headquarter at the student halls, had accidentally destroyed the building then under construction. It had killed a total of 75 workers and German soldiers and buried the architect under the ruble. Two years later, in September 1946, the university's rebirth took place, accompanied by speeches by the rector in front of 800 guests and the promotion of the first honorary doctors. The event

Note: The author would like to thank the editors as well as Hans Buhl, Tyge Krogh, Palle Lykke, Josephine May, Mogens Rüdiger and Signild Vallgårda for useful comments and information.

ə OpenAccess. () 2022 Ning de Coninck-Smith, publiziert von De Gruyter. (cc)BY Dieses Werk ist lizenziert unter einer Creative Commons Namensnennung 4.0 International Lizenz. https://doi.org/10.1515/9783110731378-016 
spurred several publications, written by some of the main protagonists about the early days of the university.

This chapter sets out to discuss what is told and is not told when university histories, and especially jubilee histories, are written. In the first part of my contribution, I will show how a narrative about the origins of Aarhus University was created by an inner circle of men with different stakes in the genesis, but also how the process was contested to such a degree that some of the disagreements were addressed in private correspondence. Taken together, it becomes clear, that the writing of the history of the university was not a given thing. How this history was written mattered as meaning-making, it mattered to identities, for self-perception and individual legacy, and it mattered as a conflictual and entangled process, where actual lives within academia crossed memoirs, newspaper clippings, private documents and correspondence.

The chapter is anchored in an understanding of the university as something done or performed by different, but interacting, men and women, as a process which is embodied in everyday routines with all the passions, conflicts and emotions, power, hierarchies and expectations, but also materialities and buildings this involves. ${ }^{1}$ In the second part, I therefore continue my reflections on the uncovering of the untold stories by twisting the narratives surrounding the university's origins and by focusing on how the first temporary lecturer in English was employed at Aarhus University. In the final section, I reflect on the making of university history in a dual and entangled sense: as jubilee histories and as stories of academic everyday life.

\section{September 1946: A New Beginning}

Let us return to that solemn inauguration event in September 1946 in Aarhus, with its rows of men in white ties and tailcoats, accompanied by their wives in evening dresses and pretty hats. The chair of the university board, the mayor, the minister of education, the rector and the chair of the building committee spoke at length about the building, the efforts and financial support of local entrepreneurs, the city council and state authorities, which had made this happen. The speakers praised how students and teachers would benefit from the special design of the new university. According to the rector, the linguist and pro-

1 De Coninck-Smith, Ning: Gender encounters university - university encounters gender: affective archives Aarhus University, Denmark 1928-1953. In: Women’s History Review 29:3 (2020). pp. $413-428$. 
fessor Ad. Stender-Petersen (1893-1963), the building would be like a real 'Alma Mater', greeting its students with open arms, love and comfort. In accordance with modern work techniques, which demanded efficiency also of academic labor, each institute had been equipped with a library, study and teaching spaces and offices. The teachers would move their research out of their private homes and students and teachers could meet and mingle in the lobby, at the libraries or in the offices. The new building complex was part of the campus design plan, which had its origins in the very early days of the university after the First World War. It stood in stark contrast to the University of Copenhagen with its many dispersed buildings and residence halls, where students - especially from the province - could easily get lost.

Apart from a few references to the long and winding road to get this far, the history of the university's first opening in 1928 was not on the speakers' agenda even if the inauguration event took place on the same date, the $11^{\text {th }}$ of September, that would be remembered as the founding day. According to the mayor, the history could be studied in several recently published books. What really mattered to the festive orators now was the present; the collaboration among Nordic universities, the cooperation between Aarhus and Copenhagen, and the importance of science in order to re-build the post-war world. "Science demands everything from man", as the chairman of the university board Carl Holst-Knudsen phrased it. With the new building, Aarhus University had made a major step to advance the working conditions of teachers, scientists and students. ${ }^{2}$

2 Anon.: Aarhus Universitets Indvielses- og Promotionsfest den 11. September 1946. Beretning udgivet efter Aarhus Universitets Lærerforsamlings Foranstaltning af Universitetets Rektor”. In: Acta Jutlandica, Aarsskrift for Aarhus Universitet XIX,1 (U 4) (1947). p. 7. 


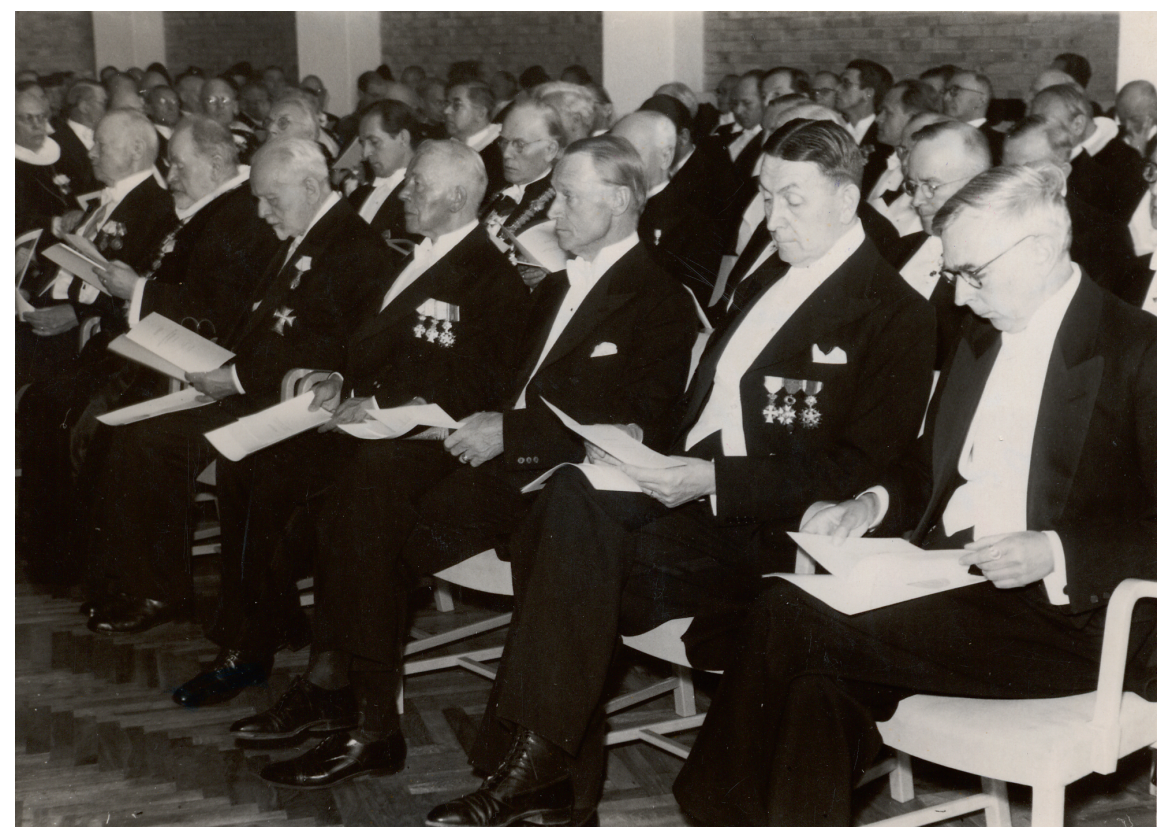

Abb. 9: Inauguration of the new main building of Aarhus University on September 11, 1946, 18 years after the university's founding. At this occasion, the first eight honorary doctors were promoted. The professor of medicine Knud Faber, who had played a central role in the creation of Aarhus University, can be seen at the very left of the first row. Unknown photographer, photograph from the Aarhus University History archive. ${ }^{3}$

3 The photograph is accessible on the website "Fotos fra Indvielses- og Promotionsfesten 1946" [Photos from the inauguration and promotion festivities 1946]. https://auhist.au.dk/showroom/ galleri/begivenheder/indvielses-ogpromotionsfest11.september1946/fotosfraindvielses-ogpromo tionsfesten1945/ (15.2.2021). 


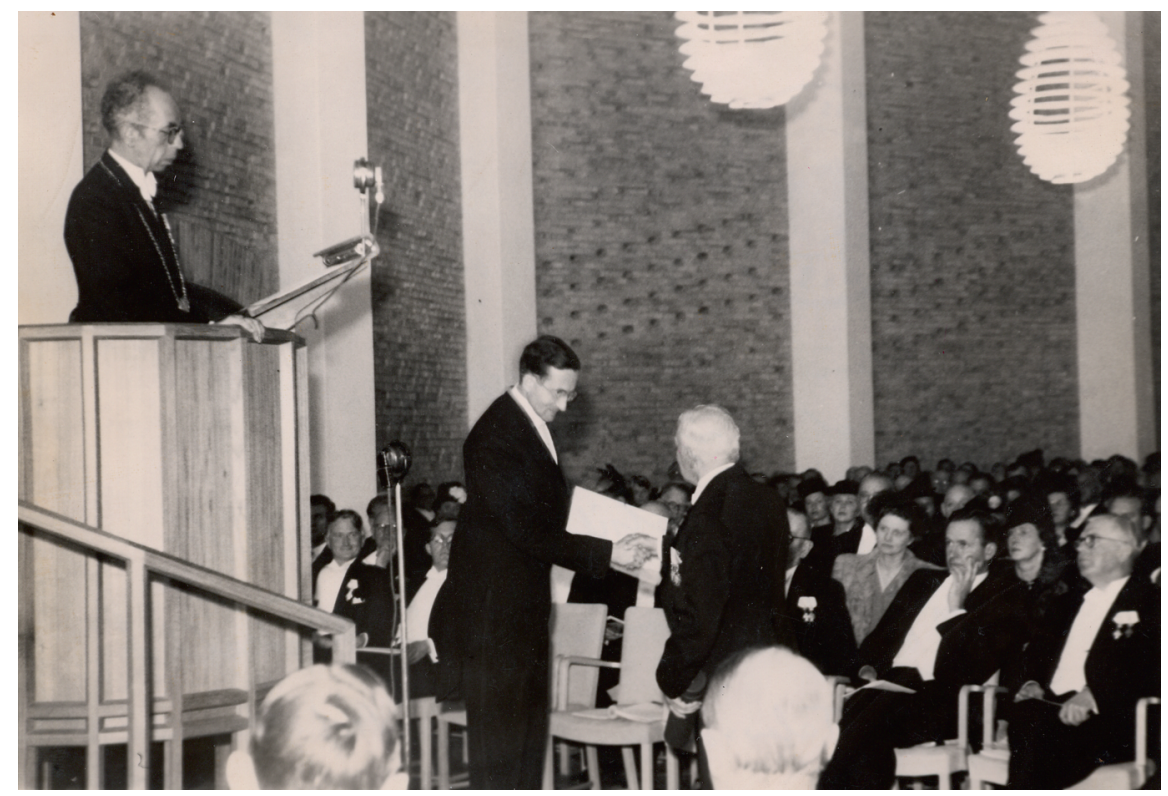

Abb. 10: Rector and professor of Slavonic languages Ad. Stender-Petersen is overseeing the process of promoting one of the many honorary doctors at the celebration in September 1946. Stender-Petersen is wearing the rector's chain which had been donated to Aarhus University in 1935 by the chairman of the university board, Carl Holst-Petersen. Like the promotion of honorary doctors, the rector's chain was an important emblem of the new university other than academic gowns which were not put into use, despite Knud Faber's commendation. Faber had in 1928 also suggested a cantata to mark the beginning of the new university. For the promotion celebration in 1946, a new cantata had been created (libretto: Tom Kristensen, music: Knud Jeppesen).

Unknown photographer, photograph from the Aarhus University History archive. ${ }^{4}$

\section{3: History on the Agenda}

Seven years later, when Aarhus University celebrated its 25 years anniversary, the set up was identical, with speeches and the promotion of honorary professors. However, it was also different. The party lasted for three days from September 11 to September 13,1953, with the university campus turned into a festive area with

4 "Fotos fra Indvielses- og Promotionsfesten 1946" [Photos from the inauguration and promotion festivities 1946]. https://auhist.au.dk/showroom/galleri/begivenheder/indvielses-ogpromo tionsfest11.september1946/fotosfraindvielses-ogpromotionsfesten1945/ (15.2.2021). 
shooting booths, carrousels and bands playing. And the university had decided that the jubilee should include the publication of its first official history. The author was Andreas Blinkenberg (1893-1982), professor of Roman philology and a former rector of the university. The task had obviously not been easy and, in the preface, Blinkenberg explained that he had chosen to write an institutional story, despite running the risk that this approach would result in a rather 'abstract' and 'dry' history. The alternative would have been an anecdotal history focusing on the individuals who "embodied the ideas and made history," frequently in dramatic situations, as he wrote. ${ }^{5}$

Blinkenberg's choice might echo his position among the first five employed in 1928. With a background in the arts and humanities, it is not surprising that he showed most knowledge of the changes within the faculty of humanities, while developments within the faculties of medicine, law and economics and theology were described in less detail. A number of statistics were included that underpinned the impression of a university that had grown more and faster than predicted. A list of employees (which did not include the first woman, the laboratory assistant and engineer Ingrid Beck, employed in 1936) and the inclusion of the most important laws and regulations completed this image.

Despite his desire to leave personal conflicts aside, Blinkenberg mentioned how the personal interests and personalities of his colleagues had influenced the design of the courses. "In these cases, history was definitely a result of the men, their temperament, ambitions and other limitations in their outlook," he wrote. ${ }^{6}$ These personal conflicts and tensions had intensified during the years 19311934, before the final approval of the humanities courses by the state authorities and the subsequent appointment of the university's first tenured professors. Tensions rose especially among those who were among the Aarhus "faculty pioneers" but still feared their jobs were under threat from external applicants. In the end, though, everybody had been working for the same goal: the founding of an independent university with four faculties. And the perceived threat never materialized, as all seven of those who had first been employed as lecturers were now being promoted to professors. ${ }^{7}$

Blinkenberg's comments and his selection of narratives made me curious. Which opaque - untold - stories was he referring to? How did these subtexts connect, cross or challenge the institutional narrative which he had been composing? Blinkenberg's narrative was taken to heart by the rector of the university,

5 Blinkenberg, Andreas: Aarhus Universitet 1928-1953. København 1953. p. 7.

6 Blinkenberg, Aarhus Universitet (cf. note 5), pp. 37-38.

7 Blinkenberg, Aarhus Universitet (cf. note 5), pp. 38-40. 
the professor in Danish language Peter Skautrup (1896-1982), in his remarks which opened the anniversary festivities in 1953. Skautrup simply held that "The need was there - the university had to come," adding that names were not necessary: "We all know who they were - and some are even present today." What really mattered, according to Skautrup, was the spirit of unity, the will to fight - and the massive public support, which had made wealthy business people and local citizens donate money and valuables, even before university teaching [Universitetsundervisningen $i$ Jylland] had become a reality. ${ }^{8}$

\section{Storylines and Contestations: Using and Doing History}

Rector Skautrup was not the first who used history to consolidate the image of Aarhus University. Since the very first days of the campaign for a second Danish university at the end of the $19^{\text {th }}$ century, history had served as an important tool for its advocates. ${ }^{9}$ A story about the future university's genesis had already entered the appendix to a 1925 parliamentary report on the possibilities of establishing a university in Jutland. Roots were traced back to the Renaissance, when several Danish kings had supported the idea of a university located in the later provinces of Schleswig and Holstein. However, nothing came of it, and during the next two centuries, several proposals were put forward for a Danish 'academy of higher learning' to be located in the city of Viborg, an administrative nexus with a high density of lawyers, pastors and teachers. The Copenhagen Fire of 1728, which hit the University of Copenhagen hard, initially made this idea an attractive one. Nevertheless, the decision was made to rebuild and restructure the university infrastructure in Copenhagen (dating back to 1479), since the idea of moving the university to Jutland had raised too much opposition.

By 1925, the arguments for establishing a second Danish university were presented in the aforementioned appendix. They referred to the importance of bringing Danish "Bildung” to the border region between Germany and Denmark; the need to create a better educational balance between Copenhagen and the rest of the country; the advantages of having two competing academic environments to

8 Beretning om Jubilæums- og Promotionsfesten [Report on the jubilee festivities in the Aarhus University. Report for the academic year 1953/54. p. 19]. https://auhist.au.dk/fileadmin/www. auhist.au.dk/filer/Fest_-_Jubilaeums-_og_Promotionsfesten_1953.pdf (14.2.2021).

9 See the list of publications in Blinkenberg, Aarhus Universitet (cf. note 5), pp. 219-221. 
drive scientific development; and the over-enrolment of students at Copenhagen University after the war. Especially the Faculty of Medicine was suffering from a lack of facilities and teachers in the mid-1920s, but studies within the humanities were also high in demand due to a growing need for high school teachers. ${ }^{10}$

A key figure in this long process was Victor Albeck (1869-1933), chief obstetrician at the Birth Clinic in Aarhus. As a member and, from 1926 onwards, chair of Universitets-Samvirket, [The University Cooperative] he was pivotal in the process of lobbying among local politicians and business men to bring the university to Aarhus. Albeck published an expanded version of the 1925 ministerial account, focusing on the arguments for establishing a faculty of medicine in Aarhus. ${ }^{11}$ In 1929, Albeck and another of the first five Aarhus employees, the associate professor in German Christen Møller, cut the long history short and focused on the latest developments in a pamphlet, which also included clippings from the parliamentary debates. It was a story about a difficult beginning, which also involved the disappointment when the original dream of a new university with a faculty of medicine as its core had to be abandoned for financial and political reasons, as well as due to academic opposition from the faculty of medicine at the University of Copenhagen. The planned medicine faculty was replaced by much cheaper foundational and private courses in philosophy and modern languages. Albeck's and Møller's story was also one of local support and trust from the city council, the inhabitants of Aarhus and wealthy business people, and it described how difficulties and skepticism were overcome. ${ }^{12}$

Albeck died a few months before the inauguration of the first university building in September 1933, but others were ready to continue the history-writing and to ensure that his and their contributions were not forgotten. This inner circle of authors included Albeck's comrade in arms, the Copenhagen-based professor of medicine Knud Faber (1862-1956), local politician and member of the Danish Parliament for the Social-Democratic Party Axel Sneum (1879-1958), and, behind the scenes, another Copenhagen-based professor, historian Erik Arup (1876-1951), as well as Erling Stensgård (1876-1966), head librarian at Aarhus State Library.

10 Hendriksen, Georg: Arbejdet for Oprettelse af et Universitet i Jylland indtil Kommissionens Nedsættelse, in Betænkning afgiven af Udvalget om Oprettelse af et Universitet i Jylland. København 1925. pp. 189-198.

11 Albeck, Victor: Arbejdet for Oprettelse af et Universitet i Jylland inden Kommissionens Nedsættelse. s.l. 1925.

12 Albeck, Victor and Chresten Møller: Arbejdet for Oprettelsen af et Universitet i Aarhus. Aarhus 1929. 
As was mentioned by the Social-Democratic major of the city of Aarhus, Svend Unmack-Larsen (1893-1965) in his speech at the inauguration of the main building in September 1946, several historical narratives about the coming-into-being of Aarhus University had recently been published. The authors were the very members of the above-mentioned inner circle. Three publications stood out in Unmack-Larsen's speech. Among them were two memoirs: The memoirs of Knud Faber from 1946 were entitled Opbygningen af Aarhus Universitet [The creation of Aarhus University]. And the memoirs of Axel Sneum, published in 1946, bore the title Da vi started Aarhus Universitet [When we started Aarhus University]. ${ }^{13}$ The two men had been positioned very differently in the creation process. Faber was located in Copenhagen with close ties to the faculty of medicine, the government and the ministry of education. Sneum was a Social Democratic member of Parliament and had close connections to the city council. It is hardly surprising that their versions of the founding story differed. While Knud Faber had written from an elitist academic perspective about the negotiations at the University of Copenhagen and at the ministry of education, Axel Sneum had taken a popular approach, stressing the good will of the city council and the inhabitants of Aarhus. In contrast to Faber's description of the importance of patience, caution and networking, Sneum accentuated the shrewdness of the local decision makers when it short-circuited and sped up the approval process through various methods like paying a summer visit to the King at his summer residence, which was located outside Aarhus. ${ }^{14}$ In a third publication also from 1946 and with the title Danmarks nye Universitet. Et overskue [Denmarks new university. An overview], the future rector Peter Skautrup presented an institutional approach, based on the university yearbooks and legal documents. ${ }^{15}$

One issue which touched two related questions caused strong disagreement around 1946, though: namely the question who had, in 1927, managed to steer the ship through the treacherous waves caused by a financial crisis, a change of government and by skepticism, if not direct resistance, from the faculty of medicine at Copenhagen? And which had been the decisive argument for the ultimate success, that is the founding of Aarhus university? This dispute went back to 1931, when the head librarian of the State Library in Aarhus, Erling Stensgård, had been invited to write his biographical entry to Kraks Blaa Bog [Who is Who in Denmark] and later repeated his version of the founding story in Acta Jutland-

13 Faber, Knud: Opbygningen af Aarhus Universitet. København 1946; Sneum, Axel: Da vi startede Aarhus Universitet. København 1946.

14 Sneum, Aarhus Universitet (cf. note 13). p. 87.

15 Skautrup, Peter: Danmarks nye Universitet. Et overskue. Aarhus 1946. 
ica, the Aarhus University Yearbook in 1933. At both occasions, Stensgård presented himself as the man, who had come up with a proposal, which had led straight to the establishment of Aarhus University. According to this narrative, Stensgård had publicly aired his idea at a dinner party in June 1927 which had marked the 25-year anniversary of Aarhus State Library. ${ }^{16}$

Stensgård's description contrasted with how Albeck and Møller had depicted the events in their 1929 version of the early history of Aarhus University. In their contribution, they claimed that it was professor Erik Arup, who had cherished considerable sympathy for the idea of a second university in Aarhus, and who ultimately had managed to transform the various loose ideas suggested by, among others, the head librarian in the preceding years, into a serious and coherent plan. The idea was to give up the plan for a medical school and begin with private university tuition in modern languages and philosophy and then gradually gain state approval and funding. ${ }^{17}$

Erling Stensgård's claim to fame, though, was partially supported by Axel Sneum and Peter Skautrup in 1946. To Sneum, the decisive argument had been a wish to relieve the University in Copenhagen from an overload of new students through the creation of elementary teaching in philosophy, Danish and modern languages in Aarhus upon the proposal by Stensgård and later picked up in the press by Arup. Skautrup seemed to agree with this chronology. ${ }^{18}$ Head librarian Stensgård took this as an acknowledgement of his key role and sent his anonymous review of Skautrup's 1946 book for a local newspaper to Erik Arup. ${ }^{19}$ Arup's reply letter shows that the discussion on who had pioneered the idea that got the ball rolling towards the future state approval of the university in 1931 also mattered to him. In his reply, Arup did not dispute that Stensgård had come up with the idea of introductory courses in modern languages, thereby accepting that establishing a faculty of medicine in Aarhus was not a possibility at that moment. However, Arup stressed in his response to Stensgård, that Stensgård had not mentioned establishing a one-year philosophy course. Instead, he himself, Erik Arup, had done so, and this had been the real game changer. ${ }^{20}$ Because, the approval of this course by the state authorities meant

16 Acta Jutlandica (1933), p. VIII; see also Erling Stensgård levnedsberetning [autobiography] 4.2.1939, Ordenskapitlet.

17 Albeck/Møller, Arbejdet (cf. note 12), pp. 29-30.

18 Skautrup, Danmarks nye Universitet (cf. note 15), p. 9.

19 The Royal Library, Copenhagen, Erik Arup's archive, Aarhus Venstreblad 13.9.1946; the letter from Stensgård to Arup has not been preserved in Arup's archive, only the newspaper clip, sent to Arup from Steensgaard.

20 The Royal Library, Copenhagen, Erik Arup’s archive: Arup to Stensgård, 25.9.1946. 
an approval of university teaching in Aarhus, as the introductory course in philosophy [filosofikum] was a precondition for university studies at all faculties. The importance of the matter led Arup to send copies of his reply to Stensgård to Knud Faber and to Peter Skautrup - as well as to the chair of the board of Aarhus University, Carl Holst-Knudsen (1886-1956). The latter had, also in 1946, published a text on the collaboration between city and university in the early years of Aarhus University. ${ }^{21}$ Arup's decision to circulate copies of his correspondence with Stensgård might have prompted Faber to inform Arup in late September 1946 that he had sought to set the record straight in his own version of the story. Faber's opinion was that Erling Stensgård had not played a role of any importance in the founding of the university "regardless what he thinks."22 Faber had expressed this view already in 1932 in a booklet about Aarhus University's past and present. ${ }^{23}$

In 1953, Andreas Blinkenberg in his 25-year anniversary history would share the honor between Arup and Stensgård without delving into whether the courses in modern languages or the philosophy course had been more important. ${ }^{24}$ With this, it could have been expected that that the dispute was settled and would attract no further attention. But quite the opposite was the case.

In 1978, Gustav Albeck (1906-1995), professor in Danish language and literature at Aarhus University, decided to set the record straight. In a new history of Aarhus University, marking its 50th anniversary, Gustav Albeck based his version of the story on his father's private archive: on the correspondence of the late Victor Albeck, the obstetrician in Aarhus who had in the 1920s actively lobbied for a medical school. In a letter from January 1927, about five months before the above-mentioned dinner party for the jubilee of Aarhus State Library, Knud Faber recommended Victor Albeck to abandon the idea of a medical school, replace it with public lectures within the humanities, and push the city council to build a small auditorium to host the lectures. Faber considered that there was a whole series of Copenhagen emeriti professors who gladly would travel to Aarhus to teach such public lectures. In case Victor Albeck was interested, he

21 Holst-Knudsen, Carl: Nogle Bemærkninger om Forholdet imellem Aarhus kommune og Aarhus Universitet. In: Acta Jutlandica 18:1 (1946). pp. 3-14; Letters from Arup to Skautrup, Faber and Holst-Knudsen in Erik Arup's archive.

22 The Royal Library, Copenhagen, Erik Arup's archive: Faber to Arup, 29.9.1946.

23 Faber, Knud: Aarhus Universitet. Dets fortid og nutid. København 1932. p. 18.

24 Blinkenberg, Aarhus Universitet (cf. note 5), p. 20. 
might as well approach Erik Arup to whom Knud Faber had spoken and who would be happy to assist in further developing the idea. ${ }^{25}$

From another letter from July 1927, it became clear, that Erik Arup was not only eager to see a second Danish university, but also eager to find a position for the philosopher Kort K. Kortsen (1882-1939). Kortsen was by that time holding a temporary position as a lecturer in Danish language at the University of Reykjavik. His term was nearing its end and because of his health, a renewal was not an option. As a member of the Danish-Islandic foundation overseeing Danish language and culture teaching in Reykjavik, Arup felt obliged to help Kortsten to get a new job. He therefore recommended Victor Albeck to hire Kortsen to teach philosophy courses in Aarhus. Albeck followed the advice. The board of university teaching in Jutland invited Kortsen for an interview and succeeded to persuade him to apply, although there was no pension and the position would - again - be temporary. ${ }^{26}$

Gustav Albeck's reference in 1978 to the private correspondence between his father Victor Albeck and Knud Faber thus supported a narrative which had been created years before by the inner circle of protagonists: It held that the university had had a difficult birth and that only a mixture of local funding, shrewdness plus a good instinct for the political game, intense networking and a handful of persistent advocates had made the start happen. However, even the letters between Albeck and Faber did not really solve the question of who had developed the decisive idea, and it is probably fair to say that Aarhus University had several committed fathers. And it is also fair to state that this was not a completely untold or unknown history, since Stensgård had claimed at several occasions that he had been the man with the bright idea. What had been untold, at least publicly, were the reactions by Erik Arup and Knud Faber. This testifies to the affective part of the story. To be remembered by history mattered to all of them, regardless of whether they made a public claim or not. Nevertheless, it was the $11^{\text {th }}$ of September 1928 which stood out as the date of foundation in all the above-mentioned publications, even if the festive inauguration of the main building on the $11^{\text {th }}$ of September 1946 would become a reference for Aarhus University's later history.

25 Letter from Faber to Albeck, 16.1.1927. In: Albeck, Gustav: Bidrag til det jyske universitets forhistorie, Universitetsforlaget i Aarhus, 1978. p. 135.

26 Letter from Arup to Albeck, 6.7.1927. In: Albeck, Bidrag (cf. note 25), pp. 138-139; regarding the decisions at the board meeting see Forhandlingsprotokol for Universitetsundervisningen i Jylland 14.4.1928-17.4.1939, Aarhus Universitets arkiv, Rigsarkivet, meeting 5.5.1928. 


\section{Twisted and Entangled Academic Lives}

On this September day of 1928, 68 students, four lecturers and one professor attended the inauguration of Universitetsundervisningen $i$ Jylland [university teaching in Jutland] together with the minister of education, the local initiators, and representatives from the University of Copenhagen and the Aarhus City Council. When the year was over, the number of students, who took classes on a weekly basis at the top floor at the Technical School, had risen to 78. ${ }^{27}$ While the 1928 inauguration did not make headlines in national newspapers, is was, as Knud Faber claimed in 1932, the day of birth of the university, "even if it was still far from fully developed"; the birth of its ties with the city of Aarhus, and the start for its new employees. As a greeting to the new institution and as a statement of its local importance, the city authorities had decorated the streets with flags. $^{28}$

Before granting its acceptance of the new higher learning institution in Aarhus that would ultimately lead to the inauguration in September 1928, the Danish ministry of education had demanded, that the Copenhagen faculty of philosophy approved the plans. This was not as easy as it might have seemed, and the members of the faculty went through highly emotional discussions before they accepted the proposal to set up elementary university teaching at Aarhus with a 32:30 vote. The critics warned against an undermining of academic standards, if research assistants were assigned to do the teaching job instead of university professors with a substantial academic record. But the majority thought it a foreseeable risk, due to the private and local support of the courses, with no prospect of state funding (yet). And the risk should further be reduced by establishing the condition that the candidates for the teaching positions in Aarhus should undergo an academic selection process. ${ }^{29}$

As a result, a selection committee was set up comprising three Copenhagen professors for each of the five open teaching positions in Aarhus. The position for English language teaching stood out, since two of the five applicants for this position were women. Behind the scenes, Victor Albeck shared his opinion with Knud Faber. He found that the two female applicants Grethe Hjort (1903-

27 Skautrup, Danmarks nye Universitet (cf. note 15), p. 11.

28 Faber, Aarhus Universitet (cf. note 23), p. 20; see also Skautrup, Danmarks nye Universitet (cf. note 15), p. 11.

29 Blinkenberg, Aarhus Universitet (cf. note 5), pp. 21-22. 
1967) and Johanne Stockholm ${ }^{30}$ were "presumably the best qualified" for the position, as they were also recommended by the renowned linguist Otto Jespersen, professor at the University of Copenhagen. ${ }^{31}$ One week later, a letter from history professor Erik Arup to Victor Albeck mentioned two other applicants, both were men. The first was Torsten Dahl (1897-1968), an assistant professor at the Copenhagen English department. The second was an Englishman named O. T. Pryce/Price ${ }^{32}$, who in Arup's opinion had put himself in an impossible position by swapping his British citizenship for a German, despite his anti-German writings. Arup also knew that one of the professors from the English department in Copenhagen had voted for Torsten Dahl and that one of the others might have voted for Grethe Hjort, who, like Dahl, held a temporary position at the University of Copenhagen. A third faculty member had voted for "the Englishman". ${ }^{33}$ In a draft for an update to Knud Faber, who was on vacation in France, Erik Arup wrote: "Please find some news from the battlefield". In the letter, Arup repeated his opinion that the British professor was non-eligible. It therefore would be "better to pick Torsten Dahl." 34

The selection committee handed in its recommendation at the end of August 1928. By then, the number of applicants for the English teaching position had risen to five. All three committee members agreed that the four Danes were talented scholars with sound teaching experience, good language skills and thus could be considered as "academic prospects." However, since none of them had written anything of a character enabling the members to properly assess their academic prowess, the committee felt forced to conclude that any selection on these grounds would be unfair and arbitrary. Given the temporary nature of the position, the committee's majority, which consisted of the professors Brusendorff and Bøgholm, opted for Pryce. They argued that Pryce would bring something to Aarhus that had so far not existed in Copenhagen, namely teaching by a native speaker. This argument was contested by the committee's third mem-

30 The archive Bryn Mawr College holds no information about Stockholm's date of birth or death.

31 The Royal Library, Copenhagen, Knud Faber's archive: Victor Albeck to Knud Faber, 20.7. 1928.

32 According to the local newspaper Aarhus Stifttidende, Pryce had been employed at Kiel University, but fled to Denmark due to 'nationalist extremism' and then gave lectures at the University of Copenhagen. Pryce/Price was in his fifties and had written a series of books on English language and literature. The newspaper most likely (mis)spelled his name as P.P. Price, see: Anonym.: Engelsk Docent i Engelsk? [An Englishman teaching English?] Aarhus Stifttidende, 28.8. 1928.

33 Aarhus University archive, Victor Albeck's archive: Erik Arup to Victor Albeck, 1.8.1928. 34 The Royal Library, Copenhagen, Erik Arup's private archive: Arup to Faber, 21.8.1928 (draft). 
ber, professor Bodelsen. His opinion was that academic positions in Denmark should be filled with Danes. And he feared that Pryce's lack of proficiency in Danish would cause problems when teaching elementary English. Once again stressing the temporary nature of the position, Bodelsen suggested to vote for Torsten Dahl because of his good exam results, language skills and his teaching experience. ${ }^{35}$

Postponing the decision until September was not acceptable to the board of "University Teaching in Jutland" in Aarhus, who had decided to start the courses by the beginning of September 1928. Something happened that must have overruled the committee's resolution right on time, because at the board meeting on the final day of August, Torsten Dahl was listed as the new lecturer in English. Dahl was granted the lowest salary of all the new employees, and in contrast to the other men on the list of employees, his first name was not added until later. This could be a coincidence or it could be due to the controversy surrounding the appointment and the fact that the decision was made at the last minute. ${ }^{36}$

\section{Careers on the Move}

Contrary to what Arup had told Faber, none of the two female applicants, Grethe Hjort and Johanne Stockholm, were taken into consideration by the members of the selection committee. The gold medal from the University of Copenhagen, which Grethe Hjort had received for her master's thesis at the age of 23, was obviously not enough to assess her academic skills. Shortly thereafter, both women left Denmark. Hjort travelled to the United Kingdom, where she earned a PhD from Newnham College for women before being appointed as Pfeiffer research fellow (1931-34) at Girton College for women in Cambridge (UK). In England, Grethe Hjort changed her name to Greta Hort and became a British citizen. Hjort/Hort then pursued an international career which took her to Australia as rector of the Women's College at the University of Melbourne and later to Prague, where she studied Old Testament texts and worked as a translator, collaborating with her life partner, the geographer Julie Moscheles (1892-1956). In 1939, Moscheles had escaped the Nazi occupation of Czechoslovakia to take up a position as professor at the University of Melbourne. The two women had met through their involvement in the Czechoslovak exile branch of the Red Cross So-

35 Københavns Universitet, Det humanistiske fakultet 1920-1975, journalsager 1920 IT-1940, kasse 21, journalsag IT-1 Universitetet i Jylland, læg: Ansøgninger 1928: Indstilling Aage Brusendorff and Niels Bøgholm, 20.8.1928; Indstilling Aage Bodelsen, 23.8.1928.

36 Forhandlingsprotokol (cf. note 26). 
ciety which Greta Hort presided. ${ }^{37}$ In 1957, after the death of Julie Moscheles, Hort returned to Denmark as Grethe Hjort. She took up a position as lecturer in English at Aarhus University and was appointed full professor in 1958. Torsten Dahl became her closest colleague until her death in 1967. Meanwhile, Johanne Stockholm had travelled to the United States, where she gained a PhD from Bryn Mawr College, a women's liberal arts college. She remained in the U.S. and taught for 28 years as an associate professor at Sweet Briar College in Virginia, a womenonly college specializing in horse riding.

The trajectory of both women was similar to many of the first generations of female academics who left their country of birth to pursue their research interests abroad. An analysis of the students who attended Girton and Newnham women's colleges before 1939 shows that the majority of these female scholars, like Stockholm and Hjort, later took up positions within university and college teaching. ${ }^{38}$ According to Torsten Dahl, who wrote an obituary for Grethe Hjort, she had left her home country because "she could not see an academic career for herself in Denmark." ${ }^{39}$ Dahl honored Hjort's efforts to spread knowledge of Commonwealth literature in Denmark, her expertise in Shakespeare's plays and her research into English poetry from the Middle Ages. At the core of Dahl's obituary was a personal portrait of Hjort, where he underlined how her life reflected the conflicts between Anglo-Saxon and Danish academic cultures. Hjort had prioritized efficiency over academic freedom, he wrote; she had been a lone wolf, but also enjoyed the company of others; she had been self-centered, but at the same time curious and helpful. She had demanded a lot of both herself and others and sacrificed her sleep to find time to write. An important character trait was her willingness to fight for recognition of her academic competences "without being aggressive.” Dahl here referred to Grethe Hjort's lifelong effort to establish herself within academia. ${ }^{40}$ These efforts had sometimes led to disappointments that Hjort could not shake off with a smile. Dahl's text was eloquent and balanced without hiding some of the tensions in his friendship with Hjort.

37 For biographical information on Greta Hort see: http://adb.anu.edu.au/biography/hort-greta10549 (14.2.2021); and: https://www.kvinfo.dk/side/170/bio/451/ (14.2.2021); on Julia Moscheles see: https://cs.wikipedia.org/wiki/Julie_Moschelesov\%C3\%A1 [in Czech, translated to Danish] (14.2.2021).

38 Goodman, Joyce et al.: Travelling careers. Overseas migration patterns in the professional lives of women attending Girton and Newnham before 1939. In: History of Education 40:2 (2011). pp. 179-196.

39 Grethe Hjort (1903-1967). https://auhist.au.dk/showroom/galleri/personer/grethehjort19031967/ (14.2.2021); see also the Torsten Dahl's obituary on Grethe Hjort. https://auhist.au.dk/ showroom/galleri/personer/grethehjort1903-1967/nekrologovergrethehjort/ (15.2.2021).

40 Torsten Dahl (cf. note 39). 
The memoirs of a former student at the department describe the sometimes strained relationship between the two English professors, by recounting how energetically Grethe Hjort, in contrast to Dahl, who had a tendency to fall asleep during classes, would teach her courses. After many years abroad, her English language skills were superior to Torsten Dahl's: "Dahl obviously had to swallow a few bitter pills after her arrival."41

In 1946, Dahl was decorated with the Order of the Dannebrog by the King of Denmark. As was custom, he had written an autobiographical statement for the occasion. In it, he recalled his childhood, wife and family life and his academic career, conceding that he had suffered from writer's block. "My academic publications could easily be overlooked, since they are so few," Dahl wrote, adding that he could have gained a name as an author if writing academic texts had come as easily to him as composing songs for festive occasions. Dahl admitted that he had been given the chance of a lifetime when appointed as a lecturer in Aarhus in 1928. And he stressed that all that had mattered to him ever since had been teaching and supervising his students. ${ }^{42}$

Dahl did not mention - and might not have known - that his initial appointment had not been a smooth ride. Nor did he mention that his promotion to full professor in 1934 had been contested by the Copenhagen faculty of philosophy because of his limited academic merits. By contrast, the selection committee had supported Dahl's candidature, pointing out that he had spent most of his time further developing the English courses and that this should be considered a merit in its own right. From a correspondence between Dahl and two members of the selection committee we learn that Dahl had an unfinished habilitation thesis in the drawer. When things were dragging on, he began to worry about his chances. The two professors, who were also his former teachers, went to great lengths in order to comfort him. One of them even broke his oath of confidentiality to inform Dahl about the discussion within the faculty. ${ }^{43}$ Ultimately, the recommendation of his candidature was only accepted by the faculty of philosophy

41 Jørn Carlsens erindringer om Grethe Hjort. https://auhist.au.dk/showroom/galleri/personer/ grethehjort1903-1967/joerncarlsenserindringeromgrethehjort/ (14.2.2021)

42 Dahl, Torsten: Levnedsberetning [autobiography] 1946. Unprinted manuscript in Ordenskapitlet [The Chapter of the Royal Orders of Chivalry].

43 Aarhus university archive, Torsten Dahl, private archive: Niels Bøgholm to Torsten Dahl, 30. 8.1934; see also Aage Bodelsen to Torsten Dahl, 11.7.1934; see also the letter sent by the Konsistorium from 29.6.1934 to the Undervisningsministeriet on postponing the decision, and the minutes from 15.10.1934 regarding the concerns of the faculty members: Undervisningsministeriet, 2. departement, 1. kontor, Journalsager 1916-1962, box 820, journalsag 1625/34. 
because there was a rush to ensure that seven professors were in place as a condition for the final state approval of the faculty of humanities in Aarhus. ${ }^{44}$

We do not know how Grethe Hjort viewed her life or academic trajectory, nor how she experienced her return to Aarhus in 1957. She left a private, but classified archive. According to the memoirs of her above cited former student and to Torsten Dahl's obituary, she seems to have had some difficult years. Maybe because she herself was a difficult person; maybe because the university was far from accustomed to female professors, as Hjort was only the second woman to be nominated for a full professorship. In 1965, Grethe Hjort finally seems to have received broader acknowledgement for her achievements as she was both awarded the prestigious Tagea Brandt scholarship and was decorated by the King. ${ }^{45}$ Ironically, after all these years of fighting for recognition, the royal administration forgot to register her decoration and she never completed the customary autobiographical description which would depict her.

\section{Lines of Thought}

As was the case with the story about who had fathered the ultimate idea which eventually led to the creation of Aarhus University, the story about the twisted and entangled academic lives of Torsten Dahl and Grethe Hjort does not yield itself for a final conclusion. It is highly probable that there is more to say about why Dahl was preferred to Hjort and the other three applicants in 1928. And without a doubt, there is more to find out about the time Hjort spent in Australia, Czechoslovakia and later in Aarhus. The fragmented, incomplete or classified archives do not supply the answers (so far). But the dust-covered brown archival boxes with their aura of the past are able to engage the researcher's fantasy and imagination to fill the gaps and to literally "think outside of the box," as a Danish expression goes. ${ }^{46}$

I will therefore leave my protagonists aside and return to the choice Andreas Blinkenberg faced in the early 1950es after he had accepted to write the official

44 Københavns Universitet, Det humanistiske fakultet 1920-1975, journalsager 1920 IT-1940, kasse 22, journalsag IT, læg Aarhus 1934: Indstilling af Torsten Dahl, 11.6.1934; Indstilling til konsistorium 26.9.1934.

45 For the decoration of Grethe Hjort see Jyllands-Posten 5.10.1965, p. 6; on the Tagea Brandt scholarship: Tagea Brandts Rejselegat. https://da.wikipedia.org/wiki/Tagea_Brandts_Re jselegat\#1960'erne (21.2.2021).

46 Tamboukou, Maria: Archival research. Unravelling space/time/matter entanglements and fragments. In: Qualitative Research 14:5 (2014). pp. 617-633, p. 628. 
history of the first 25 years of Aarhus University. Should he choose a personal or an institutional approach? Blinkenberg opted for the latter, which seemed to make good sense. Members from the 'pioneering generations' were still around and it might not have helped Aarhus University's branding, if Blinkenberg's history had unveiled the personal conflicts, ambitions and/or incompetence of the founding fathers and early staff. There was simply no reason to step on someone's toes at that moment. Blinkenberg had his agenda as had all the others who contributed to the narratives about Aarhus University. From the start, history was a tool and an argument for the creation of a university in Jutland, and it remained central for the justification of a new Danish university. At first, history was literally made by those who were present at the inauguration of the teaching courses in September 1928. By the time of the inauguration of the main university building in September 1946, the university's history had been abundantly written by members of the pioneering generation. It was finally given official approval with the publication of Blinkenberg's jubilee history in 1953. In 1978, when the university celebrated its 50 years anniversary, the publication of letters exchanged by Victor Albeck and Knud Faber added another layer to this, by now, official story about a difficult and even dramatic beginning. The approach that I use challenges some of the silences, gaps and opacities in these narratives with the help of an affective and gendered reading of institutional as well as private archives of some of the university's founding fathers. The overall purpose is to reflect on methods of how to connect institutional history with the history of everyday life in academia.

My chapter contains two examples of how personal lives and experiences were interwoven with the political and institutional structures. My first case shows how the writing of university history was imbued with personal interests and ambitions and how decisions were made behind closed doors to sanction one version and silence another. To the professors Knud Faber and Erik Arup, librarian Erling Stensgård's share in the story was at best minimal, since he had not understood the rules of the game.

My second case shows the gendered and affective juggling with academic expectations. The status of the new university hinged on the academic qualifications of its lecturers and professors, as they were defined and sanctioned by the members of the faculty of philosophy at Copenhagen University. The case shows that in 'real life', the doings of academia gave way for interpretations. In this process, networks and timing as well as gender, qualifications and life stories gained importance. A close reading of how the first lecturer and later the two professors at the English department where employed shows how academic lives could be twisted and entangled and how this resulted in different academic chronologies: Torsten Dahl earned his professorship in Denmark 
early in life, Grethe Hjort got hers late. Dahl drew on his network and developed strategies to compensate for his 'writers block', while Hjort made use of her international experiences when fighting for academic acknowledgement.

None of these stories were considered important to be included in the official university history. This is not surprising, since the decision on what becomes part of an official, institutional history and what does not enter it can be understood as a structural phenomenon built on power, politics and gender. By its very nature, the seemingly non-spectacular routine of selecting and employing the first staff for the incipient university had, as other controversies surrounding the early days in Aarhus, to be invisible and its discovery was and is left to the re-reading and creative imagination of later researchers. During this process, I have gradually come to understand university archives as a kind of holy grails loaded with emotions and affection, power and politics, the told and the untold stories. This is exactly why the stories they contain ring so familiar. ${ }^{47}$

My approach from a close reading and gender perspective has focused on those moments when the archival material became 'affectively involving' or even glowing and thereby related to my own academic experience. ${ }^{48}$ Following the feminist theoretician Maria Tamboukou's neo-materialist readings of archival work, we should not expect the story to lay in the archive, just waiting to be told by the researcher. Rather, the story and thus university (jubilee) history is a becoming or potentiality, a product of the researcher's own involvement and spatio-temporal rhythms. ${ }^{49}$

Does a gendered and affective reading change the history of Aarhus University in a substantial way? The answer is both no and yes. It does not change the meta-narrative about a difficult beginning and a 'glorious' result. But it changes the way the story is told by moving the focus from the non-personal, institutional and political towards focusing on how universities are done in the course of their everyday routine and, thus, by demonstrating that individual views and passions, conflicts and emotions were central to the development of the second Danish university.

47 De Coninck-Smith, Gender (cf. note 1).

48 Timm Knudsen, Britta and Carsten Stage (eds.): Affective Methodologies. Developing Cultural Research Strategies for the Study of Affect. Basingstoke 2015. p. 7.

49 Tamboukou, Archival research (cf. note 46), p. 631; Tamboukou, Maria: Feeling narrative in the archive. the question of serendipity. In: Qualitative Research 16:2 (2016). pp. 151-166, p. 151, p. 152. 